\title{
PROCEEDINGS OF THE THIRTY-FIRST ANNUAL MEETING
}

\author{
BY HAROLD MAYFIELD, SECRETARY
}

The Thirty-first Annual Meeting of the Wilson Ornithological Club was held on Friday and Saturday, April 28 and 29, 1950, at the State 4-H Camp, Jackson's Mill, West Virginia. It was sponsored by the Brooks Bird Club and the Huntington Bird Study Club.

There were four half-day sessions devoted to papers and motion pictures, two general business meetings, and a meeting of the Executive Council. In addition to the official sessions of the Wilson Ornithological Club, there were other events: an informal reception following the Annual Dinner on Friday evening; a tour of the Camp grounds and an informal meeting on Saturday evening, featuring motion pictures, "Wild Flowers of the Alleghenies," by H. P. Sturm, and a lecture, "Who Killed Cock Robin?" by Dr. F. W. Preston; bird walks on Friday and Saturday mornings; and field trips to the CheatGaudineer region and to Holly River State Park on Sunday, April 30. An exhibit of handmade articles, products of Southern Highlands craftsmen, was displayed.

This meeting will be long remembered for the beautiful setting in which it was held. The West Virginia hills were becoming green and the early spring flowers were in bloom. Perfect weather prevailed and every stroll across the Camp grounds was a field trip. Pileated and Red-bellied Woodpeckers were nesting near the meeting hall, and the songs of the Bachman's Sparrow and Carolina Wren were daily attractions.

\section{Meeting of the Executive Council}

The meeting of the Executive Council was held in the lobby of Harrison Cottage, at 4:00 p.m., Thursday, April 27. The principal actions of the Council were as follows:

Upon invitation of the Davenport Public Museum, the Council voted to hold the Thirtysecond Annual Meeting on Friday and Saturday, April 27 and 28, 1951, at Davenport, Iowa. A meeting of the Executive Council will be held on Thursday, April 26, and there will be field trips on Sunday, April 29.

David E. Davis asked to be relieved of the editorship of The Wilson Bulletin, but consented to continue in the post until a successor could be found. After a lengthy discussion of the matter, the Council voted that the resignation be accepted with regret.

George M. Sutton was elected Editor of The Wilson Bulletin beginning with the September, 1950 , issue.

The Council recommended that abstracts of papers presented at annual meetings not be published henceforth in the Proceedings. The considerations in making this decision were as follows: The abstracts take up space which might better be used in publishing complete ornithological papers; the abstracts are usually not complete enough to warrant bibliographical reference; most of the papers of sufficient value are later published in full in The Wilson Bulletin or some other ornithological journal. 


\section{Opening Ceremonies}

Dr. C. T. Neff, Jr., Vice President of West Virginia University, opened the general meeting on April 28 with an address of welcome. Dr. Olin Sewall Pettingill, Jr., President of the Wilson Ornithological Club, responded for the organization.

\section{First Business Session}

President Pettingill called to order the first business session on Friday morning. The minutes of the Thirtieth Annual Meeting, as published in The Wilson Bulletin for September, 1949, were approved.

The Treasurer's report was read, but action on it was deferred until after the report of the Auditing Committee at the final business session. The Treasurer's Report is published in the June, 1950, issue of the Bulletin.

\section{Report of Endowment Committee}

Leonard C. Brecher, Chairman, reported that six new life memberships were added during the year. A list of prospective life members is being compiled, and the committee will welcome the suggestions and help of all members. Life membership donations go into the endowment fund to provide steady income for the Bulletin and other activities of the club.

\section{Report of Research Committee}

John T. Emlen, Jr., reporting for Charles G. Sibley, Chairman, recommended that the Louis Agassiz Fuertes Research Grant of $\$ 100$ be awarded to Arnold J. Petersen for a study, "Reproductive Cycle in the Bank Swallow." George M. Sutton announced that an extra $\$ 100$ had been made available by an anonymous donor to this fund. This additional grant was divided as follows: $\$ 50$ to Henry E. Childs, Jr., for "Population Dynamics and Life History of the Brown Towhee"; $\$ 25$ to Harrison B. Tordoff for "Comparative Osteology of the Subfamilies of the Fringillidae"; and \$25 to Byron E. Harrell for "Ecology of the Rancho Del Cielo, Tamaulipas, Mexico." There were nine applicants for grants.

\section{Report of Membership Committee}

Seth H. Low, Chairman, reported that the names of 229 prospective members enrolled since the 1949 meeting were posted for the inspection of members. These people were to come up for election to membership at the final business session. On April 30, 1950, the Club had 1543 members and 125 institutional subscriptions to the Bulletin.

\section{Report of Illustrations Committee}

Robert M. Mengel, Chairman, reported that this committee had consulted with the editor and had given him specific assistance as follows:

1. Advised the editor about numbering, sequence and quality of illustrations (1 paper).

2. Redrawn a number of graphs and maps (about 11 for 3 papers).

3. Provided a frontispiece in color for the March, 1950, issue of The Wilson Bulletin.

4. Assembled photographs for use in connection with one future paper.

5. In addition, the Chairman has reviewed two books, consisting largely of illustrative material, for The Wilson Bulletin.

\section{Report of Committee on Aid to European Ornithologists}

Miss Theodora G. Melone, reporting for Mrs. Frances Hamerstrom, Chairman, recommended that this committee not be reappointed for another year, in view of the fact that the condition of scientists in Europe has improved so much in the past year. Mrs. Hamerstrom, 
who has just returned from a visit in Europe, has brought back a first-hand account of this situation. She tells of the great appreciation of the people in Europe who have received gift parcels. Through the combined efforts of several American societies, more than 3000 packages had gone to European ornithologists about a year ago and many more have gone since that time. As an evidence of his appreciation, one scientist donated a valuable collection of bird skins from eastern Europe and Asia to the Museum of Zoology, University of Michigan.

\section{Temporary Committees}

The president appointed three temporary committees as follows:

\section{Auditing Committee}

Leonard Brecher, Chairman

Frederick V. Hebard

\section{Resolutions Commitiee}

James Tanner, Chairman

Aaron M. Bagg

Fred T. Hall

\section{Nominating Committee}

R. Allyn Moser, Chairman

A. W. Schorger

S. Charles Kendeigh

\section{Second Business Meeting}

The second and final business meeting was called to order at 9:00 a.m., Saturday, April 29, by President Pettingill. All candidates for membership to the club were elected.

\section{Report of Library Committee}

George J. Wallace, Chairman, reported that since the publication of the list in the March, 1949, Bulletin 61 books, 78 magazines and bulletins, 1104 reprints, and 6 pamphlets have been added to the library. The committee is assembling and re-listing all of the book titles that have been published in annual lists in September Bulletins from 1943 to 1949. It is hoped that these may be published all together in an early issue of the Bulletin, thus informing members about the books (not separates and journals) in the Club's library.

\section{Report of Auditing Committee}

The Auditing Committee reported that the books of the Treasurer had been examined and found to be in good condition. Special commendation was expressed to Burt L. Monroe, retiring Treasurer, for the systematic methods and meticulous accuracy of his records.

\section{Election of Officers}

A. W. Schorger, reporting for the Nominating Committee, proposed the following officers for 1950: President, Maurice Graham Brooks; First Vice President, Walter J. Breckenridge; Second Vice President, Burt L. Monroe; Secretary, Harold Mayfield; Treasurer, James H. Olsen; Elective members of Executive Council, Richard H. Pough (term expires 1951), W.

C. Vaughan (term expires 1952), Fred T. Hall (term expires 1953).

The report of the Nominating Committee was accepted and the nominees were elected. 


\section{Report of Resolutions Committee}

The Resolutions Committee presented the following resolutions, which were adopted:

1. RESOLVED, That the Committee on Arrangements for the 1950 Annual Meeting at Jackson's Mill be highly commended for the excellent and imaginative planning that made this meeting a thorough success.

2. RESOLVED, That the Wilson Ornithological Club express its gratitude to the following groups or individuals whose efforts and generosity have contributed to the success of this 1950 meeting: to the Brooks Bird Club and the Huntington Bird Study Club-sponsors of the meeting; to West Virginia University for the use of the 4-H Camp at Jackson's Mill; to Mr. C. H. Hartley, Director of the West Virginia 4-H Camp; and furthermore, that the chairman of the Committee on Arrangements be requested to forward this expression of gratitude to the individuals or appropriate officials.

3. RESOLVED, That the officers of the Wilson Ornithological Club and the members of the various committees be commended for their inspiring leadership and able efforts during the past year; and further, that the Club express its gratitude to three retiring officers for their unceasing and often unrecognized efforts on behalf of this organization - to the retiring President, Olin Sewall Pettingill, Jr.; to the retiring Editor, David E. Davis; and especially to the retiring Treasurer, Burt L. Monroe, for five arduous years of service.

4. RESOLVED, That the Wilson Ornithological Club express its gratitude to the members of the Committee for the Relief of European Ornithologists for the time and effort they have volunteered in such a good cause.

5. WHEREAS the Wilson Ornithological Club has in the past sponsored the establishment of an air-space reservation in the Wilderness Area of the Superior National Forest, and WHEREAS a Presidential Proclamation has been declared establishing such an air-space reservation to become effective at a later date; and

WHEREAS the opponents of this reservation have been active in attempting to have this proclamation withdrawn; be it

RESOLVED, that the Wilson Ornithological Club reaffirm its support of the establishment of this air-space reservation; furthermore be it

RESOLVED, that the Secretary of this Club be directed to send a copy of this resolution to the President of the United States.

\section{Announcements}

Among the resolutions adopted at the 1949 meeting was one urging the designation of Cranberry Glades in West Virginia as a Natural Area. The United States Forest Service has taken this action.

Groups interested in serving as hosts to the Wilson Ornithological Club at the 1952 meeting should write to the Secretary before April, 1951.

\section{AnNual Dinner}

The Annual Dinner was held on Friday evening, April 28. Olin Sewall Pettingill, Jr., President of the Wilson Ornithological Club, served as toastmaster and gave the principal address.

\section{FIELD TRIPS}

On Sunday morning, April 30, members and guests visited the Cheat-Gaudineer region in the high Alleghenies and Holly River State Park. 


\section{PAPERS Sessions}

\section{Friday Morning, A pril 28}

1. Henri C. Seibert, Ohio University, Observations on the Roosting Flight of Herons (slides, 15 minutes)

2. A. O. Ramsay, McDonogh, Maryland, Some Conditioned Responses in Crowes (slides, 10 minutes)

3. James T. Tanner, University of Tennessee, Black-capped and Carolina Chickadees in the Great Smoky Mountains (slides, 15 minutes)

4. Oliver S. Owen, Cornell University, The Vertical Zonation of Song-Perches in a Central New York Woodlot (slides, 10 minutes)

5. James H. Jenkins, University of Georgia and Georgia State Game and Fish Commission, A Comparison of the Food Habits of the Barn Owl in the Piedmont and Lower Coastal Plain of Georgia (slides, 15 minutes)

6. Emerson Kemsies, University of Cincinnati, Summary of the Changes in Ohio Bird Life Since the Publication of Lynds Jones' Catalog of Ohio Birds in 1903 (15 minutes)

7. W. J. Breckenridge, University of Minnesota, Activities of Wintering Goldeneyes (slides, 10 minutes)

\section{Friday Afternoon, April 28}

8. Maurice Brooks, West Virginia University, The Unglaciated Appalachian Highland: The Region and its Characteristics (15 minutes)

9. J. J. Murray, Lexington, Virginia, Biotic Zonation in the Southern Appalachians (15 minutes)

10. Eugene P. Odum, University of Georgia, Distribution and Population Density of Birds at the Southern End of the Appalachians (slides, 15 minutes)

11. Arthur Stupka, Gatlinburg, Tennessee, Notes on Some Breeding Birds of the Great Smoky Mountains National Park (15 minutes)

12. Frederick V. Hebard, Philadelphia, Pennsylvania, The St. Mary's, Georgia, Region Seventy Years After Brewster (motion picture, 30 minutes)

13. John T. Emlen and Robert Nero, University of Wisconsin, Experimental Studies on Territory Relationships in the Red-winged Blackbird (slides, 15 minutes)

14. Aretas A. Saunders, Norwalk, Connecticut, Song in Relation to Subspecies (15 minutes)

15. R. Wayne Bailey and Hans G. Uhlig, Conservation Commission of West Virginia, Charleston and Elkins, West Virginia, Factors Influencing the Distribution and Abundance of the Wild Turkey in West Virginia (12 minutes)

\section{Saturday Morning, A pril 29}

16. Dale A. Zimmerman, University of Michigan, First Impressions of the Birds of Jalisco, Mexico (slides, 20 minutes)

17. David E. Davis, Johns Hopkins University, The Growth of Starling Populations (slides, 15 minutes)

18. Aaron Moore Bagg, Holyoke, Massachusetts, Meterological Accompaniments of Goose Flights in the Midwest, October 20-26, 1949 (slides, 20 minutes)

19. Stephen W. Eaton, St. Bonaventure College, A Comparative Study of the Genus Seiurus (slides, 20 minutes)

20. Southgate Y. Hoyt, Cornell University, The Feeding Technique of the Pileated Woodpecker (slides, 15 minutes)

21. Harvey I. Fisher, University of Illinois, East-West Distribution of Birds in the Hawaiian Archipelago (slides, 15 minutes)

22. G. Ronald Austing and Worth Randle, University of Cincinnati, A Report on Feeding Habits of Wintering Long-eared Owls and Saw-whet Owls in Southwestern Ohio (15 minutes) 


\section{Saturday Afternoon, A pril 29}

23. Hal H. Harrison, Tarentum, Pennsylvania, Natural Color Portraits of Some West Virginia Birds (slides, 30 minutes)

24. William L. Rhein and Edward S. Frey, Harrisburg, Pennsylvania and Lemoyne, Pennsylvania, The Northern Raven in Pennsylvania (motion picture, 40 minutes)

25. W. Bryant Tyrrell, Tacoma Park, Maryland, Roseate Spoonbills (motion picture, 40 minutes)

26. George M. Sutton, University of Michigan, Bird Life of the Far North (motion picture taken by Henry C. Kyllingstad, 45 minutes)

\section{ATTENDANCE}

Three hundred twenty-one members and guests, representing 19 states of the United States and one province of Canada, registered at the meeting. Next to West Virginia, Michigan was the state with the largest attendance. The list of members and visitors follows:

From Connecticut: 7-Allison L. Kampf, Bridgeport; Richard A. Kampf, Bridgeport; Mr. and Mrs. Roy C. Kampf, Bridgeport; Roy C. Kampf, Jr., Bridgeport; Mr. and Mrs. Aretas A. Saunders, Norwalk.

From Georgia: 8-J. Fred Denton, Augusta; William W. Griffin, Atlanta; James H. Jenkins, Athens; David W. Johnston, Athens; Mrs. Charles Neal, Demorest; Bill Odum, Athens; Eugene P. Odum, Athens; Martha H. Odum, Athens.

From Illinois: 6-Amy G. Baldwin, Chicago; Karl E. Bartel, Blue Island; Leona Draheim, Chicago; Mr. and Mrs. H. I. Fisher, Urbana; Mrs. Ethel M. Henwood, Urbana.

From Indiana: 8-Mrs. Kenneth Campbell, Indianapolis; James B. Cope, Richmond; Mr. and Mrs. M. S. Markle, Richmond; Stephen W. Simon, Richmond; Mrs. C. S. Snow, Richmond; Margaret Umbach, Fort Wayne; J. Dan Webster, Hanover.

From Iowa: 4 - C. C. Hazard, Davenport; Norwood C. Hazard, Davenport; Fred T. Hall, Davenport; Bud Johnson, Davenpart.

From Kentucky: 8-Wm. H. Banks, Jr., Louisville; Leonard C. Brecher, Louisville; Nelson Leach, Ashland; Harvey B. Lovell, Louisville; Georga Martin, Ashland; Mr. and Mrs. Burt L. Monroe, Anchorage; Burt L. Monroe, Jr., Anchorage.

From Maryland: 23-Mr. and Mrs. Elting Arnold, Chevy Chase; Patricia Arnold, Chevy Chase; Sarah B. Arnold, Chevy Chase; Florence H. Burner, Baltimore; Orville W. Crowder, Baltimore; David E. Davis, Baltimore; Pearl Heap, Baltimore; Mrs. Alice S. Kaestner, Baltimore; Mrs. M. C. Kent, Baltimore; Seth H. Low, Laurel; William McHoul, Baltimore; Gilbert Miller, Spring Gap; Helen B. Miller, Spring Gap; Alfred O. Ramsay, McDonogh; Walter D. Ramsay, McDonogh; Miss T. M. Sandy, Baltimore; Mrs. H. P. Strack, Baltimore; R. Thomas Thayer, Hagerstown; Jane Tuttrup, Derwood; Mr. and Mrs. W. Bryant Tyrrell, Tacoma Park; W. D. Walker, Sr., Kitzmiller.

From Massachusetts: 1-Aaron M. Bagg, Holyoke.

From Michigan: 42-H. Lewis Batts, Jr., Ann Arbor; Hazel L. Bradley, Jackson; Mr. and Mrs. Edward M. Brigham, Jr., Battle Creek; Edward M. Brigham III, Battle Creek; Julie Brigham, Battle Creek; Robert D. Burns, E. Lansing; Mr. and Mrs. W. Powell Cottrille, Jackson; N. L. Cuthbert, Mt. Pleasant; Joyce Delaney, Albion; Clara Dixon, Albion; Jess Foote, Albion; John L. George, Ann Arbor; Charles O. Handley, Jr., Ann Arbor; G. Bryan Harry, Ann Arbor; Richard Hauke, Ann Arbor; Philip S. Humphrey, Ann Arbor; Dorothy Jackson, Albion; Bernard Johnson, Albion; Mrs. Reuben L. Kahn, Ann Arbor; Cecil C. Kersting, Muskegon; Agnes Kugel, Grand Rapids; Harry Laurie, Albion; Martha A. Lengemann, Imlay City; Mr. and Mrs. Robert M. Mengel, Ann Arbor; Mrs. Alice D. Miller, Dearborn; Mr. and Mrs. Walter P. Nickell, Bloomfield Hills; Philip G. Niemann, Detroit; William Oliver, Mt. Pleasant; Virginia Olmsted, Plymouth; Mrs. P. J. Reynolds, Detroit; Merle E. Stitt, Ann 
Arbor; George M. Sutton, Ann Arbor; Harrison B. Tordoff, Ann Arbor; Elsie W. Townsend, Detroit; Mr. and Mrs. George J. Wallace, E. Lansing; Robert A. Whiting, Jackson; Dale A. Zimmerman, Imlay City.

From Minnesota: 8-Mr. and Mrs. W. J. Breckenridge, Minneapolis; Amy Chambers, Minneapolis; Mrs. Mary Lupient, Minneapolis; Theodora Melone, Minneapolis; Mr. and Mrs. Olin Sewall Pettingill, Jr., Northfield; Luther Rogers, Northfield.

From New Jersey: 6-Edward L. Chalif, Short Hills; Robert C. Conn, Bound Brook; Robert C. Frohling, Union; Peggy M. MacQueen, Bergenfield; Edward P. Manners, Brooklawn; Floyd P. Wolfarth, Nutley.

From New York: 15-Mr. and Mrs. Dean Amadon, New York; Frances L. Burnett, Ithaca; Marjorie Crimmings, Ithaca; Mr. and Mrs. Stephen W. Eaton, St. Bonaventure; Mr. and Mrs. J. Southgate Y. Hoyt, Etna; Mr. and Mrs. F. L. Jaques, New York; Donald Malick, Olean; Oliver S. Owen, Ithaca; Kenneth C. Parkes, Ithaca; James A. Walker, Waterloo; M. Shirley Windnagle, Ithaca.

From Ohio: 36-G. Ronald Austing, Cincinnati; Margaret Baker, Salem; William C. Baker, Salem; Mr. and Mrs. Clinton S. Banks, Steubenville; W. Hughes Barnes, New Concord; Edna Bowles, Martins Ferry; Mr. and Mrs. Keith Buchanan, Amsterdam; Robert C. Carder, Pataskala; Vera Carrothers, E. Cleveland; Mr. and Mrs. Don R. Eckelberry, Chagrin Falls; Elsie Erickson, Cleveland; Earl Farmer, Steubenville; Frank F. Ferris, Youngstown; Edith V. Folger, Oxford; Adela Gaede, Cleveland; Twila Hessin, Nashport; Lawrence Hicks, Columbus; Marion L. Hundley, Sylvania; Emerson Kemsies, Greenhills; Luella Literaty, Lakewood; H. B. McConnell, Cadiz; Harold Mayfield, Toledo; Mr. and Mrs. James H. Olsen, Worthington; Ralph E. Ramey, Columbus; Harry Roach, Cincinnati; Henri C. Seibert, Athens; Mildred Stewart, Cleveland; Mr. and Mrs. Albert R. Tenney, Torontv; Lois Lee Tenney, Toronto; John G. Worley, Cadiz; David Worley, Cadiz.

From Ontario: 4-J. Bruce Falls, Toronto; W. W. H. Gunn, Toronto; Mr. and Mrs. J. Murray Speirs, Pickering.

From Pennsylvania: 31-Dorothy Auerswald, Pittsburgh; Mal M. Crawford, Brownsville; Edward S. Frey, Lemoyne; George E. Grube, Gettysburg; Mr. and Mrs. Hal H. Harrison, Tarenium; Miss Mary Hartsough, Pittsburgh; Frederick V. Hebard, Philadelphia; Lou Hetrick, Gettysburg; Mr. and Mrs. J. J. Hommel, Pittsburgh; Walter T. Kohler, Lemoyne; James Manley, New Kensington; Mr. and Mrs. O. G. Masteller, West Alexander; Albert F. Meaden, Jr., Gettysburg; M. Graham Netting, Pittsburgh; Tony Netting, Pittsburgh; Mr. and Mrs. J. B. Paterson, Pittsburgh; Mr. and Mrs. F. W. Preston, Butler; C. Chandler Ross, Philadelphia; James B. Ross, Pittsburgh; Mr. and Mrs. Ward M. Sharp, State College; Phillip B. Street, Philadelphia; Mr. and Mrs. Merrill Wood, State College; Merrill Wood, Jr., State College; Emily C. Wood, State College.

From Tennessee: 6-Albert F. Ganier, Nashville; Mr. and Mrs. Arthur Stupka, Gatlinburg; Miss Stupka, Gatlinburg; Miss Stupka, Gatlinburg; James T. Tanner, Knoxville.

From Virginia: 7-John W. Aldrich, Alexandria; Florence Hague, Sweet Briar; Mr. and Mrs. D. Ralph Hostetter, Harrisonburg; Mr. and Mrs. J. J. Murray, Lexington; Frederic Scott, Hampden-Sydney.

From Washington, D. C.: 1-Katherine Keeley.

From West Virginia: 98-Dorothy Adalis, Weirton; Ruth Ankrom, Middlebourne; William E. Athey, New Martinsville; R. Wayne Bailey, Charleston; Elizabeth Ball, Ripley; Sarah Barber, Charleston; Lucy Barber, Charleston; Roger W. Barbour, Wheeling; Mr. and Mrs. P. C. Bibbee, Athens; Robert L. Birch, Morgantown; I. B. Boggs, Morgantown: Robert R. Bowers, Morgantown; Mr. and Mrs. J. P. Brawner, Morgantown; George H. Breiding, Elkins; Fred C. Brooks, Morgantown; Mr. and Mrs. Maurice Brooks, Morgantown; Billie Brosch, Wheeling; Virginia G. Cavendish, Huntington; E. R. Chandler, Chester; Kenneth Chiavetta, 
Elkins; Carolyn Conrad, Wheeling; Charles Conrad, Wheeling; Dorothy Conrad, Wheeling; Mary K. Conrad, Wheeling; Helen Crooks, Charleston; Malcolm P. Crooks, Charleston; Mrs. Thos. W. Curry, Buckhannon; A. P. Davisson, Fairmont; Ann Fae Dawson, Spencer; Mr. and Mrs. W. R. DeGarmo, Elkins; Ralph M. Edeburn, Huntington; Dr. and Mrs. F. M. Farnsworth, Buckhannon; Franklin E. Farrar, Weirton; Mrs. Carter L. Faust, Fairmont; Dorothy Fisher, Huntington; N. G. Florea, Wheeling; Stewart Freeman, McMechen; Lois Garrett, Kenova; Ruth Glass, New Cumberland; N. Bayard Green, Huntington; Edna Gregg, Middlebourne; Pearl Gregg, Middlebourne; J. T. Handlan, Keyser; Mr. and Mrs. John W. Handlan, Charleston; Mr. and Mrs. C. O. Handley, Sr., Charleston; Jennie Harshbarger, Fairmont; Eva H. Hays, Wheeling; Mrs. Betty Hess, Fairmont; Elizabeth Hunter, Wheeling; E. P. Jenkins, Farmington; Stacy Jennings, Charleston; Eleanor Johnson, Weirton; Frank M. Johnson, Charleston; Clifford Kidwell, Quinwood; Mary B. Kimball, Sistersville; Lester B. Koon, Fairmont; Lessie O. Koon, Fairmont; Hugh C. Land, Huntington; W. C. Legg, Mt. Lookout; J. D. Larmoyeux, Charleston; Earl N. McCue, Morgantown; Mrs. J. E. Mayfield, Clarksburg; Mrs. A. F. Millender, Clarksburg; Robert M. Moore, Morgantown; Gladys M. Murrey, Charleston; Charles R. Myers, Morgantown; Dr. C. T. Neff, Jr., Morgantown; E. M. Pollack, Beckley; Elizabeth Risen, Huntington; Mrs. James R. Robinson, Fairmont; Mr. and Mrs. Albert Routa, Clarksburg; T. R. Samsell, Elkins; A. F. Schulz, Charleston; E. A. Seaman, Charleston; Mrs. W. G. Seymour, Clarksburg; Eleanor Sims, Charleston; Ray E. Snyder, Alderson; Marjoretta Stahl, Kimberly; Sid Stephenson, Clendenin; Maxine Thacker, Charleston; Donald L. Underwood, Hurricane; Dale Van Horn, Fairmont; Earl Van Scoy, Elm Grove; Hans G. Uhlig, Elkins; Melvin J. Vorbach, Morgantown; Mrs. John R. Wagner, Glenville; Dan Walker Wheeler, Fairmont; Mrs. James W. Wheeler, Fairmont; Mary Louise Wright, Wheeling; William L. Wylie, Morgantown.

From Wisconsin: 2-John T. Emlen, Madison; A. W. Schorger, Madison.

\section{THE WILSON ORNITHOLOGICAL CLUB LIBRARY}

The following gifts have been recently received. From:

Aaron M. Bagg -5 reprints

Frederick S. Barkalow, Jr.-2 reprints, 1 pamphlet

A. M. Guhl -4 reprints

Harry W. Hann-1 reprint

F. Haverschmidt -3 reprints

Harold M. Holland-1 magazine

Margaret R. Knox-1 bulletin

Margaret M. Nice-12 reprints

Harriet B. Woolfenden-1 book 


\section{$2 \mathrm{BHL}$ Biodiversity Heritage Library}

Mayfield, Harold. 1950. "Proceedings of the Thirty-First Annual Meeting." The Wilson bulletin 62(3), 145-152.

View This Item Online: https://www.biodiversitylibrary.org/item/214548

Permalink: https://www.biodiversitylibrary.org/partpdf/208821

\section{Holding Institution}

Harvard University, Museum of Comparative Zoology, Ernst Mayr Library

\section{Sponsored by}

IMLS LG-70-15-0138-15

\section{Copyright \& Reuse}

Copyright Status: In copyright. Digitized with the permission of the rights holder.

Rights Holder: Wilson Ornithological Society

License: http://creativecommons.org/licenses/by-nc-sa/4.0/

Rights: https://biodiversitylibrary.org/permissions

This document was created from content at the Biodiversity Heritage Library, the world's largest open access digital library for biodiversity literature and archives. Visit BHL at https://www.biodiversitylibrary.org. 